\title{
Islamic Sex Education (ISE) Conceptual Model of Cognitive Theories-The Findings
}

\author{
Nurtihah Mohamed Noor, Abdul Nasir Zulkifli, Mohd Fitri Yusoff, Fadzilah Siraj \\ School of Multimedia Technology and Communication, College of Arts and Sciences, Universiti Utara Malaysia, 06010 Sintok, Kedah, Malaysia \\ *Corresponding author: nasirzul@uum.edu.my
}

\section{Article history}

Received :1 December 2013

Received in revised form :

10 January 2014

Accepted :31 January 2014

Graphical abstract

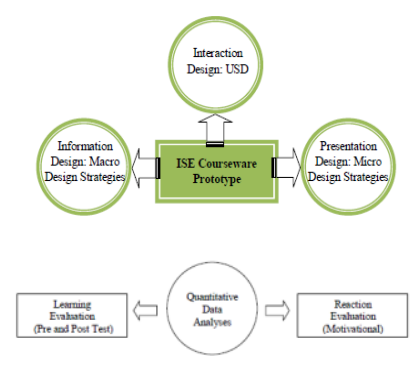

\section{Abstract}

This study proposes a conceptual model of Islamic Sex Education (ISE) and an ISE courseware based on the model; named Al-Adab, in conveying rightful sex education information to the parents, particularly Muslims. By the end of the study two evaluations were conducted namely; learning evaluation and reaction evaluation to investigate the effectiveness of the prototype as well as the constructed model with 41 respondents, which are parents. Employing the pre and post test, learning evaluation that includes 15 similar questions about ISE was given before and after the respondents used the courseware prototype. Meanwhile, the reaction evaluation was given after the respondents used the courseware prototype in assessing the overall effectiveness of the prototype. After analyzing the data, we found that the correct answers of the learning evaluation were increased after the respondents used the prototype; and overall they agreed the effectiveness of the prototype in increasing their knowledge.

Keywords: Interactive multimedia; cognitive theories; sex education; conceptual model; evaluation

\section{Abstrak}

Kajian ini mencadangkan satu model konsep Pendidikan Seks Islam (ISE) dan perisian kursus ISE berdasarkan model; yang dinamakan Al-Adab, dalam menyampaikan maklumat pendidikan seks yang betul kepada ibu bapa, terutamanya Muslim. Pada akhir kajian ini dua penilaian telah dijalankan iaitu penilaian pembelajaran dan penilaian reaksi untuk menyiasat keberkesanan prototaip serta model yang dibina dengan 41 responden, iaitu ibu bapa. Menggunakan ujian pra dan pos, penilaian pembelajaran yang merangkumi 15 soalan yang sama mengenai ISE telah diberi sebelum dan selepas responden menggunakan prototaip perisian. Sementara itu, penilaian tindak balas diberikan selepas responden menggunakan prototaip perisian dalam menilai keberkesanan keseluruhan prototaip. Selepas menganalisis data, kami mendapati bahawa jawapan yang betul daripada penilaian pembelajaran telah meningkat selepas responden menggunakan prototaip; dan secara keseluruhannya mereka bersetuju keberkesanan prototaip dalam meningkatkan pengetahuan mereka.

Kata kunci: Multimedia interaktif; teori kognitif; pendidikan seks; model konseptual; penilaian

\subsection{INTRODUCTION}

Changes in economic and technology have left a deep impact to the socio-cultural and lifestyle of the society (Mat and Saad, 2005). However, the changes have critically impacted the society through the increase of social problems, including free sex and sexual deviance problems. The problems are rapidly growing in Malaysia. In Islam, with regard to the issue of sex education, parents are the major role model in educating their children (Ulwan 1985/2002). The intervention of parents is critically needed for parental guides to their children related to sexuality matters (Ulwan 1985/2002; Walker, 2004). Nevertheless, in Malaysia, most parents are unaware of sex education (Noor et al., 2012). They are lacking in knowledge related to that particular matter (Rahman, 2010). Parents are embarrassed to learn and discuss about sex education, particularly about puberty, physical and physiological sexuality changes and others (Buston et al., 2001; Walker, 2004; Constantine et al., 2007; Jaafar and Lee, 2008; Rahman, 2010). In our preliminary investigation (PI) among 44 parents which include 20 fathers and 24 mothers of a convenient sampling, it indicated that $75 \%$ of the respondents were reluctant to discuss about sex education with their children. $79.5 \%$ of the respondents did not know and unsure about sex education and its contents. $75 \%$ of them stated that they were unclear and have inadequate information about sex education, particularly from the perspective of Islam. The respondents learned and retrieved information about sex education from books (88.6\%), VCDs (81.8\%) and the internet (63.6\%). However, the suitability of the contents was still questionable and this was reflected from the PI results where the respondents did not know and were unsure about the proper contents. Walker (2004) stated that appropriate guide for sex education is important 
to ensure the effectiveness of the parental guide. $90.9 \%$ of the respondents also agreed that they did not have enough learning materials to improve their knowledge in sex education. Irrefutable that most of the sex education learning aids (eLearning based) available are based on the non-Islamic approaches (Mat and Saad, 2005; Weerakon and Wong, 2000). Certainly, its learning model lacks in term of the Islamic approach suggestions in giving the righteous contents to the children (Maynard, 2010). Basically, their aim is to remind the children to delay sexual activities until marriage or about contraception in avoiding any unintended pregnancy (wedlock) or health issues such as by using condoms, campaigns and others. There is a dearth of sex education from the religious approach (Maynard, 2010; Mat and Saad, 2005) especially those based on Islam.

Therefore, sex education needs further transformation to pull down the 'taboo' barrier (Buston et al., 2001 and Laura et al., 2006), especially from the support of computer and technological advent (Lee and Jaafar, 2009). Changing the parents' perception about sex education is important. They must be encouraged to understand the essential of the education.

In the same vein, cognitive theory covers a broad area and has been applied in many fields of studies. Relatively, it is related to how the human think. In learning, psychologist and educators believed that both cognition and learning process is mutually beneficial. In this field, the theory is utilized to explain the human behaviour by understanding their thought processes (Mayer, 2001; Mayer, 2002). Once the thought processes are discovered, it is easier to formulate the educational settings.

From the studies of the cognitive processes, researchers tend to propose better ways in learning. Not only the way of teaching and learning environment should be, but also how to convey the information effectively, whether directly or indirectly to learners (Mayer, 2002; Noor et al., 2011). In learning, cognitive theory offers three theory-based core assumptions about how people learn from words and assumptions (Mayer, 2002). The assumptions include dual channel assumption, limited capacity assumption and active processing assumption. Table 1 briefly describes the three core assumptions. The description of every assumption projects the ability and limitation of human thinking which is related to the brain in processing information. By understanding the assumptions, the learning through multimedia technology is improved in enhancing the learners' understanding.

Thus, this study proposes an Islamic Sex Education (ISE) model and a prototype based on the cognitive theories named AlAdab. The theories are important to ensure the developed courseware prototype considers the processes of human cognitive system in the learning process.

Table 1 Three core assumptions of cognitive theories (Mayer, 2001)

\begin{tabular}{ll}
\hline Assumptions & \multicolumn{1}{c}{ Definition } \\
\hline Dual Channel & $\begin{array}{l}\text { Humans possess separate information channels } \\
\text { for processing verbal and visual information }\end{array}$ \\
$\begin{array}{l}\text { Limited } \\
\text { Capacity }\end{array}$ & $\begin{array}{l}\text { There is limited amount of capacity for processing } \\
\text { those information at one time }\end{array}$ \\
Active & $\begin{array}{l}\text { Humans engage in active learning by attending to } \\
\text { relevant incoming information, organizing the } \\
\text { selected information into coherent mental } \\
\text { representations and integrating the representation } \\
\text { with other knowledge }\end{array}$
\end{tabular}

\subsection{THE ISE CONCEPTUAL MODEL}

Conceptual model refers to researcher's theories between several factors or dimensions relationship that have been importantly identified in the research and concepts (Sekaran, 2003). According to Dalle (2010), the conceptual model helps researchers to evaluate the relationship of those elements in enhancing the understanding of the research problems and solutions. The discussion on the conceptual model implicates that the ISE was developed by referring to its conceptual model. Before the model was developed, the concepts and related studies about the selected areas particularly in sex education and cognitive theories were investigated from the literatures. The model is important in order to clarify the implementation of the ISE courseware prototype as depicted in Figure 1. The model is crucial as it suggests the important guidelines in developing the ISE courseware prototype. It emphasizes the three prominent elements in developing an effective prototype. The interaction design adapted the Usage Centered Design (USD) guidelines. Meanwhile, the macro design strategies of this study are the ISE principles which refer to the ISE contents design. The principles were referred in the light of the ISE topics proposed by Ulwan (1985/2002). Lastly, the micro design strategies of this study were adopted from cognitive theory of multimedia learning (CTML) and multimedia learning principles proposed by Mayer (2001). Further details on how the conceptual model guidelines were used in the ISE courseware prototype are elaborated in the following sections.

\subsection{Interaction Design: UCD}

As shown in Figure 1, the interaction design for this study adapted the USD as guidelines in clarifying the tasks or activities between the users and the courseware prototype. The combination of USD in the ADDIE model presents proper development and implementation processes of the ISE courseware prototype. Besides that, two models and theories are used in USD models as an attempt to make the courseware prototype more effective to the parents, and then can encourage them to learn ISE.

The ARCS (Attention, Relevance, Confidence, Satisfaction) is a widely used model (theories) related to motivation and learning. Previous studies have revealed that it can enhance learner's understanding as the model emphasizes on ways of grabbing learners' preference and attention towards a learning process.

\subsection{Information Design: Macro Design Strategies}

According to the conceptual model, the ISE contents are the main topics to be conveyed to the learners. The contents consist of nine topics which were derived from various resources related to ISE. The topics include; male and female relationship, vision and awrah care, manners in permission asking, faithful to Allah and religion, abstinence, health issues, contraception, puberty information and marriage. 


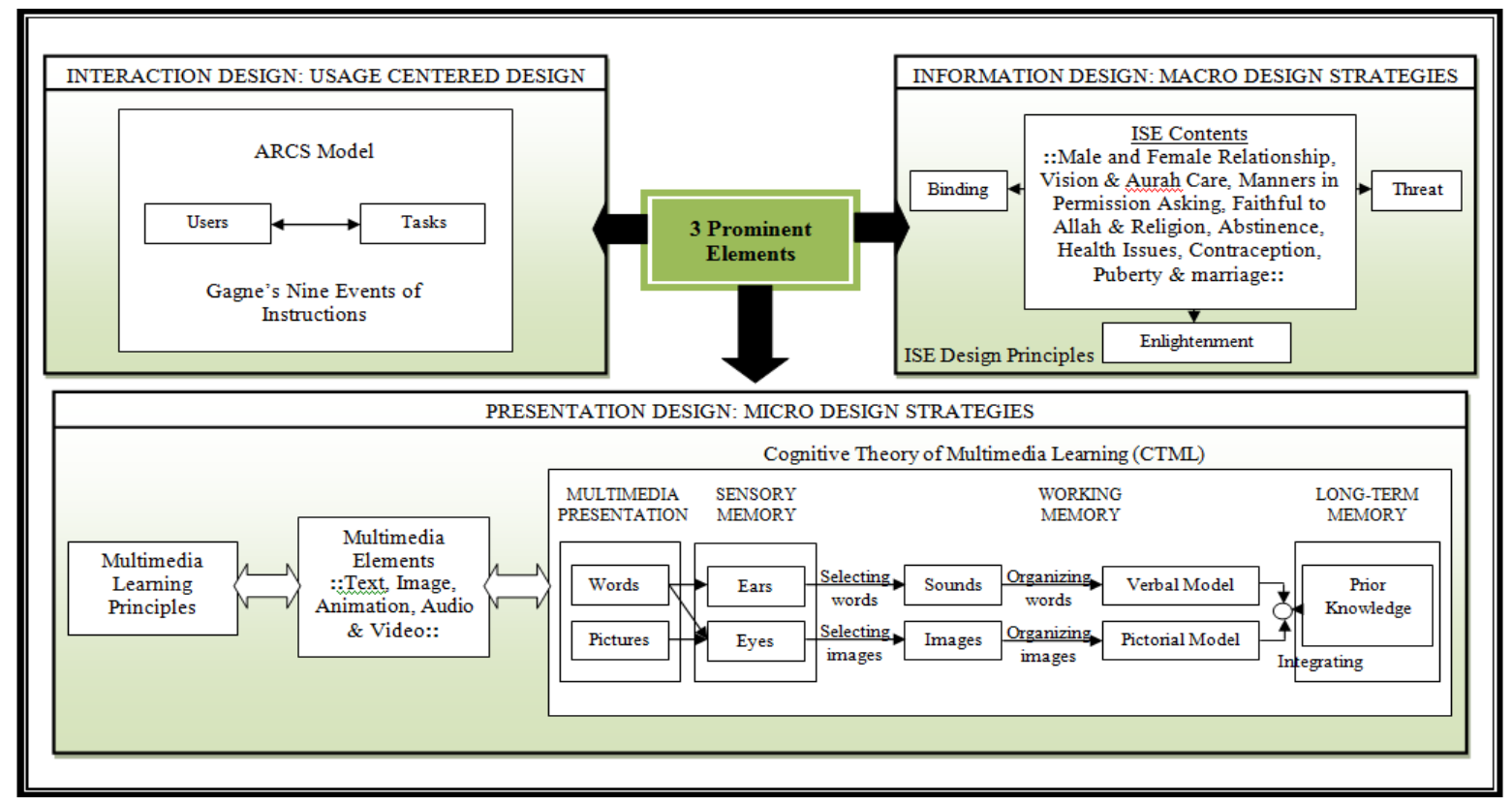

Figure 1 The ISE conceptual model

Macro strategies were used to organize and restructure a number of different ideas or information of the contents. According to Salam (2010), for macro design strategies, the use of principles is important to convey the information effectively. Therefore, the organization and restructuring of the contents must be properly guided. Furthermore, as stated by Patten et al., (1986), the organization and restructuring of the contents are essential to well-organize the memory of the learners. In order to ensure that the developed prototype is relevant to the ISE objectives, this study adapted three main principles in implementing the ISE as guidelines for the information design. The principles were applied in the topics to increase the awareness towards ISE. There are enlightenment, threat and binding principles (Noor et al., 2012).

\subsection{Presentation Design: Micro Design Strategies}

Micro design strategies were adapted for the presentation design of the contents in the ISE courseware prototype. Multimedia elements that have been applied in this study comprised of text, graphics, animation, audio and video. The presentation of the elements was guided by some principles and theory. CTML and multimedia learning principles are the most widely accepted references that have been adapted in this study. CTML assumes that human information processing includes dual channels (visual and verbal processing) whereby both channels have their limited capacity. ISE courseware prototype used both channels in presenting the ISE contents.

However, this study attempted to present the ISE contents in a minimum way to prevent any memory load as proposed by the ISE conceptual model. Besides, the courseware also promoted the users to be engaged in the active learning process whereby they can interact with the courseware. As guidelines to the CTML, multimedia learning principles were also referred. Therefore, this study adapted six principles of multimedia learning in order to increase the effectiveness of the presentation design of the ISE contents. They are multimedia principle, spatial contiguity principle, temporal contiguity principle, coherence principle, modality principle and redundancy principle.

\subsection{THE EXPERIMENTAL TESTING DESIGN}

Briefly, the experimental study or evaluation consists of several designs, namely; the after-only design, the before-and-after design, the control-group design, the double-control group design and others. In investigating the changes of users' understanding after using the ISE courseware prototype that has been developed based on the conceptual model, this study deployed the beforeand-after design of experimental testing. The before-and-after experimental design investigates the solutions by constructing 'before' observation, which is before an intervention is produced to the study population. Then, the 'after' observation is carried out whenever the intervention is completely implemented or presented to the population. It is to ascertain the impact of the new intervention to them.

This study adapted two evaluations, which are learning evaluation and reaction evaluation as suggested by the Kirkpatrick Model of Evaluation (Table 2). Out of four levels, only Level 1 and Level 2 were selected as they suit the study. The evaluation involved pre test and post test pertaining to the ISE knowledge before and after using the ISE courseware prototype. The most important thing is it also depicts the acceptable level of the constructed conceptual model based on the results gained in the post test. It shows how the model succeeded in enhancing the respondents' knowledge level. The questions from this evaluation were based on the ISE contents as suggested in the conceptual model. All the data was collected anonymously. However, each respondent's questionnaire booklet has been assigned a predetermined identification number for the purpose of data analyses. In this study, 41 respondents consisting of both Muslim fathers and mothers from various backgrounds were involved in the evaluation phase. 
Table 2 Description of Kirkpatrick's model of evaluation

\begin{tabular}{|c|c|c|}
\hline Level & Characteristic & Practicability \\
\hline 1 & Is how the delegates felt & Quick and very easy \\
\hline (Reaction) & $\begin{array}{l}\text { about the learning } \\
\text { experience }\end{array}$ & $\begin{array}{l}\text { to obtain. Not } \\
\text { expensive }\end{array}$ \\
\hline $\begin{array}{c}2 \\
\text { (Learning) }\end{array}$ & $\begin{array}{l}\text { Is the measurement of the } \\
\text { increase in knowledge } \\
\text { before and after }\end{array}$ & $\begin{array}{l}\text { Relatively simple to } \\
\text { set up; clear for } \\
\text { quantifiable skills }\end{array}$ \\
\hline $\begin{array}{c}3 \\
\text { (Behaviour) }\end{array}$ & $\begin{array}{l}\text { Is the extent of applied } \\
\text { learning on the job } \\
\text { implementation }\end{array}$ & $\begin{array}{l}\text { Requires } \\
\text { cooperation and skill } \\
\text { of line-managers }\end{array}$ \\
\hline $\begin{array}{c}4 \\
\text { (Result) }\end{array}$ & $\begin{array}{l}\text { Is the effect on the } \\
\text { business or environment } \\
\text { by the trainee }\end{array}$ & $\begin{array}{l}\text { Individually not } \\
\text { difficult, unlike } \\
\text { whole organization }\end{array}$ \\
\hline
\end{tabular}

Overall, there are two control groups for this evaluation. One of them consists of respondents who have the exposure to sex education, and the other one consists of respondents that do not have any exposure to sex education. At first, the respondents were briefed on the objectives of the evaluation and the way it would be conducted. Secondly, they were required to answer the pre test which consisted of fifteen questions related to ISE for assessing the existing knowledge and exposure of the respondents, and the questions were adapted from the Instructional Motivational Material Survey (IMMS) to investigate the respondents' reaction towards the ISE courseware prototype. Thirdly, the respondents were given ample time to explore and learn the contents of the prototype on their own without any interference from the researcher. Once they were done, they were asked to answer the post test questions.

\subsection{Learning Evaluation}

A hypothesis was used to clarify the results obtained during the learning evaluation. Pre test answers from all respondents were compared to the post test answers based on 15 multiple choice questions. The results based on the comparison were then interpreted for both parents having and not having disclosure to ISE.

Hypothesis 01: There is no significant difference in the respondents' knowledge retention mean scores between pre test and post test.

In testing of Hypothesis 01 , paired-samples $t$-test was used in comparing the respondents' knowledge retention mean scores in pre test and post test learning evaluation. The results indicated that there was a difference in mean scores between the two tests; pre test and post test, for all the respondents.

The post test results indicated higher knowledge retention mean score of 11.12 compared to only 4.27 for the pre test (Table $3)$. There was significant difference in mean score between the two tests. The respondents who were exposed to the ISE courseware prototype obtained significantly higher level of knowledge retention in the post test compared to the pre test based on the mean scores difference. Generally, the ISE courseware prototype improved the level of ISE knowledge among parents.
Table 3 Hypothesis ${ }_{01}$ paired samples t-test statistics

\begin{tabular}{lcccc}
\hline & Mean & N & Std. Dev. & Std. Error Mean \\
\hline Pre Test & 4.27 & 41 & 1.1517 & .237 \\
Post Test & 11.12 & 41 & 1.1735 & .271 \\
\hline
\end{tabular}

Table 4 shows 15 multiple choice questions and answers from pre test and post test for the learning evaluation from the two groups of respondents. Overall, both groups showed an increase in the mean scores in the post test compared to the mean scores in the pre test. Based on the above table, in pre test, parents having disclosure to ISE gained $0.476,0.286,0.571,0.286,0.286$, $0.095,0.143,0.238,0.286,0.143,0.095,0.333,0.476,0.381$, and 0.190 in mean values for question 1 until question 15 ; however, the mean values of the respondents' correct answers increased to $0.762,0.905,0.810,0.905,0.762,0.667,0.714,0.762,0.714$, $0.571,0.810,0.571,0.905,0.714$ and 0.524 after using the ISE courseware prototype as obtained in the post test.

Parents not having disclosure to ISE gained $0.450,0.350$, $0.550,0.350,0.600,0.300,0.000,0.250,0.150,0.050,0.100$, $0.250,0.400,0.250$ and 0.100 of mean values in the pre test. Similar with the other group, the mean values have increased in the post test, where they gained $0.650,0.750,0.850,0.800,0.850$, $0.900,0.850,0.750,0.800,0.850,0.850,0.650,0.600,0.450$ and 0.400 for each questions. Surprisingly, there is an increase from 0.000 of mean value to 0.850 for question number 7 for parents not having disclosure to ISE. The results indicated the overall increase in the mean value in the post test after using the ISE courseware prototype.

In pre test, parents having disclosure to ISE achieved the highest correct answers for questions $1,3,7,10,11,12,13,14$ and 15. Meanwhile, parents not having disclosure to ISE gained the highest score for questions number 2, 4, 5, 6, 8 and 9. These showed that the parents having disclosure to ISE have better knowledge ( 9 answers) about ISE compared to the parents not having disclosure to ISE (6 answers). However, for the post test, parents not having disclosure to ISE obtained 8 correct answers (3, 5, 6, 7, 9, 10, 11 and 12). Meanwhile, parents having disclosure to ISE gained 7 correct answers $(1,2,4,8,13,14$ and $15)$.

Table 4 Pre test and post test results for 2 groups of parents

\begin{tabular}{ccccc}
\hline $\begin{array}{c}\text { Question } \\
\text { No. }\end{array}$ & $\begin{array}{c}\text { Having } \\
\text { (Pre) }\end{array}$ & $\begin{array}{c}\text { Having } \\
\text { (Post) }\end{array}$ & $\begin{array}{c}\text { Not Having } \\
\text { (Pre) }\end{array}$ & $\begin{array}{c}\text { Not Having } \\
\text { (Post) }\end{array}$ \\
\hline 1 & 0.476 & 0.762 & 0.450 & 0.650 \\
2 & 0.286 & 0.905 & 0.350 & 0.750 \\
3 & 0.571 & 0.810 & 0.550 & 0.850 \\
4 & 0.286 & 0.905 & 0.350 & 0.800 \\
5 & 0.286 & 0.762 & 0.600 & 0.850 \\
6 & 0.095 & 0.667 & 0.300 & 0.900 \\
7 & 0.143 & 0.714 & 0.000 & 0.850 \\
8 & 0.238 & 0.762 & 0.250 & 0.750 \\
9 & 0.286 & 0.714 & 0.150 & 0.800 \\
10 & 0.143 & 0.571 & 0.050 & 0.850 \\
11 & 0.095 & 0.810 & 0.100 & 0.850 \\
12 & 0.333 & 0.571 & 0.250 & 0.650 \\
13 & 0.476 & 0.905 & 0.400 & 0.600 \\
14 & 0.381 & 0.714 & 0.250 & 0.450 \\
15 & 0.190 & 0.524 & 0.100 & 0.400 \\
\hline
\end{tabular}




\subsection{Reaction Evaluation}

Reaction evaluation is important in measuring the effectiveness of new interventions for instructional or learning material. It assesses whether the materials can encourage, stimulate and sustain users' learning behavior towards the learning process. Since sex education is a 'taboo' issue and most of the parents were reluctant to discuss and less concerned about the topic as explained before, this reaction evaluation has been deployed. It investigated whether the developed prototype can increase their learning motivation or awareness for learning sex education.

Besides that, both validity and reliability were addressed to measure the degree of errors in IMMS questionnaires. Validity is the degree to which the questionnaire is actually measuring or collecting data of what the researcher thinks about. Meanwhile, the reliability of a questionnaire is defined as the consistency with which the same results are achieved. In assessing the consistency between measurements of questions, the Cronbach's alpha scores were calculated by using SPSS 15.0 for Windows.

Table 5 shows that IMMS had a Cronbach alpha value of 0.76. The IMMS questionnaires were adapted from Keller (1983) and extended by Huang et al. (2006). Since the Cronbach alpha value is greater than 0.7 , then all the dimensions' measurement items are highly interrelated as suggested by Nunnaly (1978). Based on Nunnaly (1978) and Huang et al. (2006), the value of reliability of 0.70 and above was acceptable and reasonable. Thus, the IMMS items were interrelated since the alpha score is above 0.70 . For content validity, the IMMS questionnaire used in this study was well-established and developed by Keller (1983) for instructional learning material. Furthermore, it was used by many researchers such as Huang et al. (2006) and Salam (2010).

Table 5 Reliability of IMMS items

\begin{tabular}{cc}
\hline Numbers of Items Included & Cronbach's Alpha \\
\hline 18 & 0.76 \\
\hline
\end{tabular}

This study used a well-known motivational evaluation instrument which is IMMS. The most crucial part is that this evaluation also investigates the potential and effectiveness of the constructed ISE conceptual model in encouraging ISE learning. The IMMS questionnaires used in the evaluations consist of four dimensions namely; Attention, Relevance, Confidence and Satisfaction. All the four dimensions consist of 19 items. The results for all the items were compared between both groups (two groups of parents; those having disclosure to sex education and those not having disclosure to sex education) and the explanations are described in the following sub sections.

The Attention dimension consists of eight items. Table 6 shows the results for each item for both groups of parents. The results indicated that item 3 (The quality of the writing in AlAdab holds my attention) and item 7 (Al-Adab is so complete that it was easy to keep my attention on it) have high mean scores for both groups of parents. While item 6 (The variety of reading passages, diagrams, graphics and etc. helped keep my attention on Al-Adab) has the lowest mean score for both groups of parents. Based on the results also, both groups of parents agreed that the ISE courseware prototype received their Attention towards the ISE learning.

The Relevance dimension consists of four items. Table 7 shows the results for each item for both groups of parents. Generally, the parents having disclosure to sex education have higher mean scores compared to the parents not having disclosure to sex education except for item 1 . The results indicated that item 3 (There are sufficient materials (graphics, videos and etc) that showed me how Al-Adab could be important to some people who are learning Islamic sex education) has high mean scores for both groups of parents. While item 1 (I could relate the content of $\mathrm{Al}$ Adab to things I have seen, done or thought about in my own life) has the lowest mean score for both groups of parents. Based on the results also, both groups of parents agreed that the ISE courseware prototype has the Relevance value in ISE learning.

The Confidence dimension consists of three items. Table 8 shows the results for each item for both groups of parents. Generally, the parents not having disclosure to sex education have higher mean scores compared to the parents having disclosure to sex education. The results indicated that item 2 (The information in Al-Adab is acceptable and easy to be picked out and remember the important points) has high mean scores for both groups of parents. While item 1 (The exercises in Al-Adab are acceptable) has the lowest mean score for both groups of parents. Based on the results also, both groups of parents agreed that they have confidence in using the ISE courseware prototype for ISE learning.

The Satisfaction dimension consists of four items. Table 9 shows the results for each item for both groups of parents. The results indicated that item 3 (The working of the feedback and the capability to go back and review material after completing exercises made me feel rewarded for my effort) has high mean scores for both groups of parents. While item 4 (It was a pleasure to work with Al-Adab) has the lowest mean score for both groups of parents. Based on the results also, both groups of parents agreed on the satisfaction of using the ISE courseware prototype for ISE learning.

Table 6 Comparison of results for items in the attention dimension

\begin{tabular}{|c|c|c|c|}
\hline \multicolumn{2}{|r|}{ ATTENTION DIMENSION } & \multicolumn{2}{|c|}{ MEAN } \\
\hline No. & Item & Having & $\begin{array}{c}\text { Not } \\
\text { Having }\end{array}$ \\
\hline 1. & $\begin{array}{l}\text { There was something interesting at the beginning of } \\
\text { Al-Adab that got my attention. }\end{array}$ & 4.24 & 4.10 \\
\hline 2. & Al-Adab is eye catching. & 4.29 & 4.50 \\
\hline 3. & $\begin{array}{l}\text { The quality of the writing in A1-Adab holds my } \\
\text { attention }\end{array}$ & 4.43 & 4.40 \\
\hline 4. & $\begin{array}{l}\text { The way the information is arranged on the Al-Adab } \\
\text { pages helped keep my attention. }\end{array}$ & 4.24 & 4.10 \\
\hline 5. & Al-Adab has things that stimulated my curiosity. & 4.19 & 4.20 \\
\hline 6. & $\begin{array}{l}\text { The variety of reading passages, diagrams, graphics } \\
\text { and etc. helped keep my attention on Al-Adab. }\end{array}$ & 4.10 & 4.15 \\
\hline 7. & $\begin{array}{l}\text { Al-Adab is so complete that it was easy to keep my } \\
\text { attention on it. }\end{array}$ & 4.43 & 4.45 \\
\hline \multirow[t]{2}{*}{8.} & $\begin{array}{l}\text { There is no repetition information in this Al-Adab } \\
\text { that makes me feel bored. }\end{array}$ & 4.24 & 4.25 \\
\hline & Total & 4.27 & 4.27 \\
\hline
\end{tabular}

Table 7 Comparison of results for items in the relevance dimension

\begin{tabular}{llcc}
\hline \multicolumn{1}{c}{ RELEVANCE DIMENSION } & \multicolumn{2}{c}{ MEAN } \\
\hline No. & \multicolumn{1}{c}{ Item } & Having & $\begin{array}{c}\text { Not } \\
\text { Having } \\
\text { 1. }\end{array}$ \\
$\begin{array}{l}\text { I could relate the content of Al-Adab to things I have } \\
\text { seen, done or thought about in my own life. }\end{array}$ & 4.05 & 4.10 \\
2. $\begin{array}{l}\text { It is clear to me how the content of Al-Adab is } \\
\text { related to the Islamic sex education. }\end{array}$ & 4.19 & 4.15 \\
3. $\begin{array}{l}\text { There are sufficient materials (graphics, videos and } \\
\text { etc) that showed me how Al-Adab could be } \\
\text { important to some people who are leaming Islamic } \\
\text { sex education. }\end{array}$ & 4.24 & 4.15 \\
4. $\begin{array}{l}\text { The content of Al-Adab is useful to me in terms of } \\
\text { leaming the Islamic sex education effectively. }\end{array}$ & 4.19 & 4.15 \\
\hline
\end{tabular}


Table 8 Comparison of results for items in the confidence dimension

\begin{tabular}{|c|c|c|c|}
\hline \multicolumn{2}{|r|}{ CONFIDENCE DIMENSION } & \multicolumn{2}{|c|}{ MEAN } \\
\hline No. & Item & Having & $\begin{array}{c}\text { Not } \\
\text { Having }\end{array}$ \\
\hline 1. & The exercises in Al-Adab are acceptable. & 4.00 & $4.10^{\circ}$ \\
\hline 2. & $\begin{array}{l}\text { The information in Al-Adab is acceptable and easy to } \\
\text { be picked out and remember the important points. }\end{array}$ & 4.33 & 4.50 \\
\hline \multirow[t]{2}{*}{3.} & Al-Adab contains information that I can understand. & 4.19 & 4.20 \\
\hline & Total & 4.17 & 4.27 \\
\hline
\end{tabular}

Table 9 Comparison of results for items in the satisfaction dimension

\begin{tabular}{llcc}
\hline \multicolumn{1}{c}{ SATISFACTION DIMENSION } & \multicolumn{2}{c}{ MEAN } \\
\hline No. & \multicolumn{1}{c}{ Item } & Having & $\begin{array}{c}\text { Not } \\
\text { Having }\end{array}$ \\
1. & $\begin{array}{l}\text { I enjoyed Al-Adab so much that I would like to know } \\
\text { more about it. }\end{array}$ & 4.14 & 4.15 \\
2. I really enjoyed learning with Al-Adab. & 4.00 & 4.05 \\
3. $\begin{array}{l}\text { The working of the feedback and the capability to go } \\
\text { back and review material after completing exercises } \\
\text { made me feel rewarded for my effort. }\end{array}$ & 4.57 & 4.45 \\
4. It was a pleasure to work with Al-Adab. & Total & $\mathbf{4 . 2 0}$ & $\mathbf{4 . 1 8}$ \\
\hline
\end{tabular}

\subsection{DISCUSSION AND CONCLUSION}

The learning evaluation results showed that there is an increase in knowledge related to ISE in the post test results compared to the pre test results. Although the respondents were evaluated by using the ISE courseware prototype, it reflects the effectiveness of the ISE conceptual model that has been constructed to guide the design and development of the courseware prototype. The model has suggested several ISE topics and contents to be included in the ISE courseware prototype. The results indicated that the ISE knowledge among the respondents for both groups of parents has been improved. On that matter, it can be said that the constructed ISE conceptual model has the capability to increase and encourage the ISE learning based on the conducted learning evaluation results. In the same vein, the reaction evaluation depicts variety of mean results for the IMMS questionnaires which are based on ARCS model. However, overall the results showed that the ISE courseware prototype has its own potential to increase their awareness and knowledge towards the ISE learning. As in the learning evaluation, the most important is, this evaluation portrays the effectiveness and potential of the constructed ISE conceptual model.

The good results in IMMS dimensions depicted the acceptance of the ISE conceptual model that has been constructed. Clearly, the above results for ARCS dimensions showed that there are no significant differences between the results for both groups whether the respondents have or do not have the disclosure to the ISE learning. Relating to the results from the preliminary investigation (PI), even though the parents have rated that they have the disclosure to sex education or ISE, truthfully their knowledge is dubious as they also stated that most of them were unsure about sex education or the ISE contents. In Malaysia, sex education and ISE contents are still vague and not clearly exposed to the society. Nevertheless, the results showed that the ISE courseware prototype, and particularly the ISE conceptual model has its own potentials and abilities to encourage, enhance and create awareness towards the ISE learning among the targeted users.
Based on the learning evaluation and reaction evaluation, there is a significant increase in the ISE knowledge before and after the parents used the ISE courseware prototype. The reaction evaluation showed that the prototype is in the agreeable level. Both evaluations indicate that the courseware prototype and indirectly the ISE conceptual model has the potential to encourage the ISE learning process among the target users and in this case, parents.

\section{References}

[1] Buston, K., Wight, D., and Scott, S. 2001. Difficulty and Diversity: The Context and Practice of Sex Education. British Journal of Sociology of Education. 22(3): 353-368.

[2] Constantine, L. L. 2006. Activity Modeling: Towards a Pragmatic Integration of Activity Theory with Usage-Centered Design. Retrieved 5 December 2010 , http://www.foruse.com/articles/activitymodeling.pdf.

[3] Dalle, J. 2010. Metodologi Umum Penyelidikan Reka Bentuk Bertokok Penilaian Dalaman dan Luaran: Kajian Kes Sistem Pendaftaran Siswa Indonesia. Unpublished PhD Theses, Universiti Utara Malaysia, Kedah.

[4] Huang, W., Diefes-Dux, H., and Imbrie, P. 2006. A Preliminary Validation of Attention, Relevance, Confidence and Satisfaction ModelBased Instructional Material Motivational Survey in a Computer-Based Tutorial Setting. British Journal of Educational Technology. 37(2): 243259.

[5] Jaafar, A., and Lee, C. S. 2008. Design Approach of Malaysian Sexual Educational courseware (MSE) for Secondary Schools. Paper Presented at the WSEAS Conference 2008, Istanbul, Turkey.

[6] Keller, J. 1993. Manual for the Instructional Materials Motivational Survey (IMMS). Unpublished Manuscript, Florida State University, Tallahassee.

[7] Laura, B., Lindberg, J., and Singh, S. 2006. Changes in Formal Sex Education: 1995-2002. Perspectives on Sexual and Reproductive Health. 38(4): 182-189.

[8] Lee, C., and Jaafar, A. 2009. Usage-Centered Design Approach in Design of Malaysia Sexuality Education (MSE) Courseware. Visual Informatics: Bridging Research and Practice. 856-867.

[9] Mat, M. Z. A., and Saad, R. M. 2005. Konsep dan Objektif Pendidikan Seks Menurut Perseptif Al-Quran. Paper Presented at the Seminar Seksual Kebangsaan 2005, Pusat Pembangunan Keluarga, Universiti Malaya, Kuala Lumpur. Retrieved June 15, 2009, from http://muafakatmalaysia.com/2008/12/13/konsep-dan-objektifpendidikan-seks-menurut-perspektif-al-quran/.

[10] Mayer, R. E. 2001. Multimedia Learning. Cambridge, United Kingdom: Cambridge University Press.

[11] Maynard, A. 2010. Sex, Sexuality And Science-A Novice's Guide. Retrieved August 5, 2010, from http://2020science.org/2010/03/22/sexsexuality-and-science-a-novices-guide/.

[12] Noor, N. M. 2012. Al-Adab: Islamic Sex Education (ISE) Courseware Using Cognitive Theory. Master Thesis, Universiti Utara Malaysia, 2012.

[13] Patten, J. V., Chao, C. I., and Reigeluth, C. M. 1986. A Review of Strategies for Sequencing and Synthesizing Instruction. Review of Educational Research. 56(4): 437.

[14] Rahman, S. F. A. 2010. Pendidikan Seks Di Sekolah - Isu Yang Masih Belum Selesai. Retrieved 16 May 2010, from http://www.ikim.gov.my/v5/index.php?lg=1 andopt=com_articleandgrp $=2$ andsec $=$ andkey $=684$ andcmd $=$ resetall

[15] Salam, S. N. A. 2010. The Development and Effects of a Persuasive Multimedia Learning Environment (PMLE) In Reducing Children Dental Anxiety. PhD Thesis, Universiti Sains Malaysia, 2010.

[16] Sekaran, U. 2003. Research Methods for Business: A Skill Building Approach. New York: John Willey and Sons, Inc.

[17] Ulwan, A. N. 2002. Pendidikan Anak-Anak Dalam Islam (Jilid Dua). Singapura: Pustaka Nasional Pte Ltd. Original work published 1985.

[18] Walker, J. 2004. Parents and Sex Education-Looking Beyond the Birds and the Bees. Sex Education. 4(3): 239-254.

[19] Weerakoon, P., and Wong, M. 2000(a). Sexuality Education On-line for Health Professionals. Electronic Journal of Human Sexuality. 6. Retrieved October 28, 2010, from http://www.ejhs.org/volume6/SexEd.html. 